\title{
Rola cytokinin w modullacji oddzialywań symbiotycznych roślin bobowatych i bakterii wiążących azot atmosferyczny
}

\section{STRESZCZENIE}

W yróżniającą cechą roślin bobowatych jest ich zdolność do nawiązywania oddziaływań symbiotycznych z bakteriami, wiążącymi azot atmosferyczny, tzw. rizobiami. Wymiana specyficznych molekuł sygnałowych pomiędzy rośliną gospodarzem a mikrosymbiontem stanowi pierwszy etap wymagany zarówno do infekcji bakteryjnej jak i formowania nowego organu symbiotycznego jakim jest brodawka korzeniowa. Biorąc pod uwagę fakt, iż wspomniane dwa procesy zachodzą $\mathrm{w}$ różnych tkankach korzenia, $\mathrm{tj}$. $\mathrm{w}$ ryzodermie oraz komórkach kory pierwotnej, ścisła ich regulacja i koordynacja jest oczekiwana. W modulacji interakcji symbiotycznych kluczową rolę odgrywają hormony roślinne, w szczególności cytokininy. Aktywacja ścieżki sygnałowej cytokinin w korze pierwotnej stanowi kluczowy element procesu symbiozy. W jej konsekwencji aktywne biologicznie cytokininy są biosyntetyzowane i akumulowane w strefie korzenia podatnej na brodawkowanie. Zapoczątkowuje to podziały mitotyczne komórek kory pierwotnej i rozwój brodawki korzeniowej. Zrozumienie genetycznych mechanizmów regulacji, leżących u postaw zdarzeń, zachodzących $w$ wewnętrznych warstwach korzenia, stanowi jedno z kluczowych wyzwań, pojawiających się w badaniach procesów symbiotycznych.

\section{WPROWADZENIE}

Azot $(\mathrm{N})$, jako składnik szeregu związków biologicznie aktywnych (m.in. kwasów nukleinowych, białek, chlorofilu oraz fitohormonów) stanowi istotny element decydujący o prawidłowym wzroście i rozwoju roślin [1]. Pomimo, iż atmosfera ziemska stanowi bogaty rezerwuar azotu cząsteczkowego $(78 \%)$, nie może być on bezpośrednio asymilowany przez rośliny. Występowanie potrójnego wiązania kowalencyjnego pomiędzy atomami azotu utrudnia jego redukcję do form łatwo przyswajalnych [2]. Organizmy roślinne mogą pobierać azot ze środowiska wyłącznie $\mathrm{w}$ formie jonów amonowych $\left(\mathrm{NH}_{4}^{+}\right)$lub azotanowych $\left(\mathrm{NO}_{3}^{-}\right)$[3]. Ograniczona dostępność zredukowanych związków azotowych w glebie jest jednym z głównych czynników limitujących wzrost upraw i poziom plonowania. Obecnie jednym z największych źródeł przyswajalnej formy azotu są nawozy sztuczne, których produkcja wynosi około $120 \mathrm{Tg} \mathrm{N} / \operatorname{rok}\left(1 \mathrm{Tg}=10^{9}\right.$ $\mathrm{kg}=10^{6}$ ton) $[4,5]$. W krajach uprzemysłowionych, wzbogacanie gleb nawozami azotowymi wywiera jednakże negatywny wpływ na środowisko naturalne. Chemiczna redukcja azotu wymaga bowiem dużych nakładów energetycznych. Co więcej, ponad $60 \%$ azotu wprowadzanego do gleby podlega stratom w wyniku wymywania oraz utleniania do atmosfery, prowadząc m.in. do eutrofizacji zbiorników wodnych, oraz zakwaszania gleb [6]. Jednocześnie, w krajach rozwijających się, ograniczenia w produkcji i dostawach nawozów mineralnych prowadzą do niskiej produktywności rolniczej i niedożywienia [6]. Poszukiwanie alternatywy dla nawozów nieorganicznych, $w$ tym azotowych jest więc kluczowe dla zrównoważonej i bezpiecznej produkcji żywności.

\section{ZNACZENIE BIOLOGICZNEGO WIĄZANIA AZOTU}

Proces biologicznego wiązania azotu (BNF, ang. Biological Nitrogen Fixation) odgrywa szczególną rolę w obiegu azotu w przyrodzie, zarówno w ekosystemach naturalnych, jak również agrosystemach. Na obszarach lądowych dostarcza on do globalnego obiegu azotu średnio $118 \mathrm{Tg}$ N/rok, w tym 51\% stanowi azot wiązany w uprawach rolniczych [4,5]. Proces biologicznego wiązania azotu jest możliwy dzięki aktywności enzymu - nitrogenazy (EC 1.18.6.1), katalizującego reakcję redukcji azotu $\left(\mathrm{N}_{2}\right)$ do amonowej formy tego pierwiastka, który może być dalej metabolizowany w komórkach roślinnych $[7,8]$. W przeciwieństwie do organizmów eukariotycznych, zdolność wiązania azotu atmosferycznego $\left(\mathrm{N}_{2}\right)$ posiadają drobnoustroje określane wspólnym mianem diazotrofów. Grupa mikroorganizmów asymilujących $\mathrm{N}_{2}$ jest liczna oraz zróżnicowana. Wśród diazotrofów wyróżnić można zarówno organizmy wolnożyjące, niesymbiotyczne, jak również bakterie wiążące azot $\mathrm{w}$ układach asocjacyjnych oraz

\section{dr inż. Karolina Jarzyniak}

Katedra Biochemii i Biotechnologii, Uniwersytet Przyrodniczy w Poznaniu, Poznań

https://doi.org/10.18388/pb.2020_343

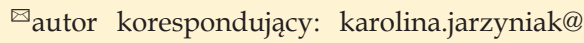
up.poznan.pl

Słowa kluczowe: Biologiczne wiązanie azotu, diazotrofia, rizobium, Medicago truncatula morfogeneza brodawki korzeniowej, cytokininy

Wykaz skrótów: APT - fosforybozylotransferaza adeninowa (ang. Adenine Phosphoribosyl Transferase); CKX - dehydrogenaza/oksydaza cytokinin (ang. Cytokinin Dehydrogenase/ Oxidase); CYP735A - cytochrom P450, rodziny 735, podrodziny A (ang. Cytochrome P450, Family 735, Subfamily A); HK/CRE1 - kinaza histydynowa (ang. His Kinase/ Cytokinin Response 1); HP - białko fosfotransferowe zawierające histydynę (ang. His-containing Phosphotransfer Protein); IPT - transferaza izopentenylowa (ang. Isopentenyltransferase); LOG - fosforybohydrolaza LOG (ang. Lonely Guy); LRR-RLK - receptorowe kinazy białkowe, zawierające powtórzenia bogate w leucynę (ang. Leucine Rich Repeat Receptor-Like Kinase); NCR - białka roślinne specyficzne dla brodawek, bogate w cysteinę (ang. Nodule-specific Cysteine-Rich); RR-A/B - regulator odpowiedzi typ A/B (ang. Response Regulator type A/B) 
symbiotycznych $\mathrm{z}$ roślinami [9]. Ze względu na różnice w złożoności systemów, w których dochodzi do wiązania azotu, wydajność procesu jest odmienna. Spośród wszystkich organizmów diazotroficznych, największą ilość azotu do środowiska glebowego (70-80\%) dostarczają asymilatory symbiotyczne, wiążąc i udostępniając azot na potrzeby metabolizmu rośliny gospodarza. W zależności od gatunku makrosymbionta oraz warunków klimatyczno-glebowych wartość udostępnionego dla roślin azotu szacowana jest na $30-250 \mathrm{~kg} / \mathrm{ha} /$ rok [10]. Wyższa, w porównaniu do diazotrofów niesymbiotycznych i asocjacyjnych, efektywność asymilacji azotu wynika ze ścisłej interakcji z rośliną gospodarzem. Zapewnienie przez roślinę odpowiednich warunków, m.in.: (i) środowiska mikroaerobowego dla nitrogenazy, (ii) źródła energii niezbędnego do redukcji azotu, oraz (iii) systematycznego obniżenia ilości azotu w komórce bakteryjnej, który hamowałoby aktywność nitrogenazy, skutkuje przesunięciem równowagi systemu w kierunku wydajnej redukcji azotu.

\section{DIAZOTROFIA W UKŁADACH SYMBIOTYCZNYCH}

Presja selekcyjna środowiska naturalnego związana $\mathrm{z}$ ograniczoną dostępnością składników mineralnych w podłożu, doprowadziła do koewolucji roślin lądowych z mikroorganizmami. Nawiązanie symbiotycznych oddziaływań stanowiło jedno z kluczowych mechanizmów adaptacyjnych, umożliwiających efektywną kolonizację siedlisk lądowych przez rośliny naczyniowe. W zamian za asymilowany i udostępniany przez mikrosymbionta azot, roślina stanowiła tzw. niszę ekologiczną, zapewniając warunki do rozwoju poprzez dostarczanie związków węgla. Wśród układów symbiotycznych diazotrofów z roślinami naczyniowymi wyróżnić należy: (i) układy z udziałem cyjanobakterii (Anabaena spp., Nostoc ssp.), (ii) aktinoryzę promieniowców (Frankia) oraz (iii) endosymbiozę rizobiów [11].

Jednym z najbardziej wyspecjalizowanych i gatunkowo-specyficznych układów symbiotycznych, odgrywającym szczególnie istotną rolę $\mathrm{w}$ agroekosystemach jest symbioza roślin z bakteriami korzeniowymi, tzw. rizobiami (łac. rhizos - korzeń, bios - życie) [12,13]. Rizobia stanowią grupę zróżnicowanych, gramujemnych diazotrofów, należących do klasy a- i $\beta$-Proteobacterii [13]. Obecna klasyfikacja rizobiów, oparta na analizach podobieństwa m.in. sekwencji genów kodujących 16S rRNA, wyróżnia 14 rodzajów a-rizobiów (Rhizobium, Mesorhizobium, Ensifer (dawniej Sinorhizobium), Bradyrhizobium, Azorhizobium, Neorhizobium, Allorhizobium, Pararhizobium, Phyllobacterium, Methylobacterium, Ochrobactrum, Microvirga, Devosia, Shinella) oraz 2 rodzaje $\beta$-rizobiów (Burkholderia, Cupriavidus), należących odpowiednio do rzędu Rhizobiales i Burkholderiales [13]. Pomimo, iż omawiane diazotrofy mogą występować w formie wolnożyjącej, w tych warunkach nie są zdolne do redukcji azotu, bytując w glebie jako saprofity. Makrosymbiontami, zapewniającymi im ekologiczną niszę (brodawki korzeniowe lub łodygowe), są rośliny należące do rodziny bobowatych (Fabaceae Lindl.) oraz klasyfikowany do wiązowatych (Ulmaceae Mirb.) rodzaj Parasponia [14]. Rośliny bobowate stanowią trzecią co do wielkości (ok. 20 tysięcy gatunków) oraz drugą pod względem znaczenia ekonomicznego rodzinę roślin okrytonasiennych. Spośród 6 sklasyfikowanych podrodzin, przedstawiciele dwóch z nich (Caesalpinioideae DC., Papilionoideae DC.) nawiązują symbiotyczne asocjacje z bakteriami korzeniowymi [15]. Wśród nich wyróżnić można rośliny o dużym znaczeniu gospodarczym, takie jak: soja (Glycine max L.), fasola zwyczajna (Phaseolus vulgaris L.), groch zwyczajny (Pisum sativum L.), soczewica jadalna (Lens culinaris Medik.), lucerna siewna (Medicago sativa L.) oraz orzech ziemny (Arachis hypogaea L.) [14]. Dzięki interakcjom symbiotycznym, bobowate stanowią bogate źródło białka. Ponadto, pełnią ważną rolę w płodozmianie zwiększając plon roślin następczych, poprzez wzbogacanie gleby w przyswajany azot. Biorąc pod uwagę fakt, iż nie wymagają dodatkowej suplementacji w azot, ich uprawa jest korzystna zarówno ze względów ekologicznych jak i ekonomicznych.

Duże znaczenie gospodarcze roślin bobowatych sprawiło, iż omawiany układ symbiotyczny stał się interesującym modelem badawczym, umożliwiającym poznanie i zrozumienie złożonych mechanizmów interakcji międzygatunkowych.

\section{MEDICAGO TRUNCATULA - MODELOWA ROŚLINA BOBOWATA}

Wzrost zainteresowania biologicznym wiązaniem azotu $\mathrm{w}$ układach symbiotycznych roślin bobowatych $\mathrm{z}$ diazotrofami wymusił poszukiwanie odpowiedniego modelu roślinnego do badań genetycznych oraz genomicznych. Spośród roślin bobowatych, dwa gatunki: Medicago truncatula Gaertn. oraz Lotus japonicus L. zostały zaproponowane jako organizmy modelowe, umożliwiające badanie procesów morfogenezy dwóch odmiennych typów brodawek korzeniowych.

W przeciwieństwie do L. japonicus, M. truncatula należy do grupy roślin IRLC (ang. the Inverted Repeat Lacking Clade), cechujących się brakiem odwróconego powtórzenia o długości $25 \mathrm{kpz}$ w genomie chloroplastowym. Opisana różnica $\mathrm{w}$ genomie ma swoje odzwierciedlenie $\mathrm{w}$ procesie symbiozy. Interakcje symbiotyczne $\mathrm{w}$ grupie IRLC charakteryzują się bowiem rozwojem brodawek z trwale funkcjonującym merystemem, wysokim stopniem kontroli rośliny gospodarza nad różnicowaniem mikrosymbionta, a tym samym wyższą efektywnością wiązania azotu $[13,16]$.

Pochodząca z rejonu basenu Morza Śródziemnego $M$. truncatula jest blisko spokrewniona z gatunkami o dużym znaczeniu gospodarczym, m.in. lucerną siewną (Medicago sativa L.), grochem zwyczajnym (Pisum sativum L.) oraz soczewicą jadalną (Lens culinaris Medik.) [13, 17]. Jednakże w przeciwieństwie do nich posiada relatywnie mały ( 465 Mpz), diploidalny genom $(2 \mathrm{n}=16)$, który został zsekwencjonowany i opisany $[17,18]$. Charakteryzuje się krótkim cyklem życiowym, wynoszącym około 4 miesiące. Jest rośliną samopylną i wysokoplenną, z dużą kolekcją ekotypów. Co więcej, jest podatna na genetyczną transformację z wykorzystaniem bakterii z rodzaju Agrobacterium. Dostępność protokołów dotyczących hodowli M. truncatula, jak również, jej transformacji, in- 
(a)

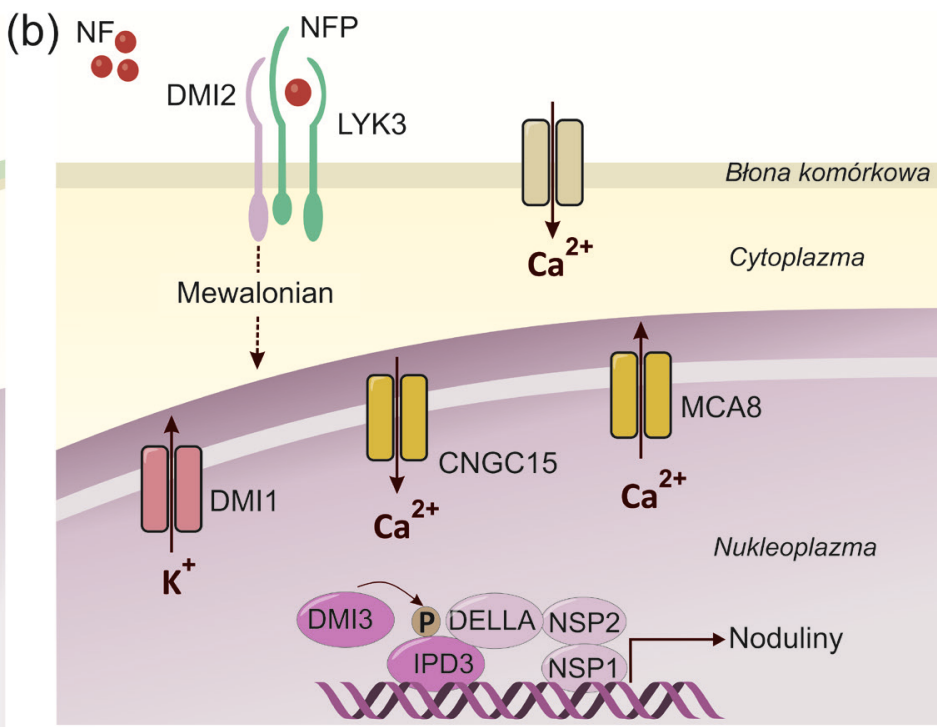

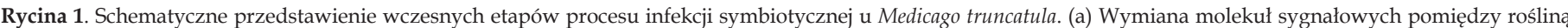

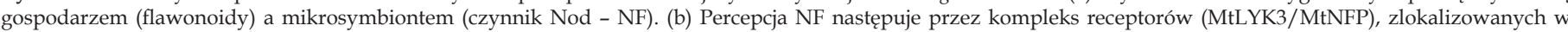

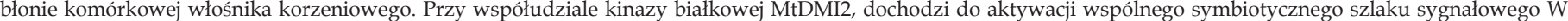

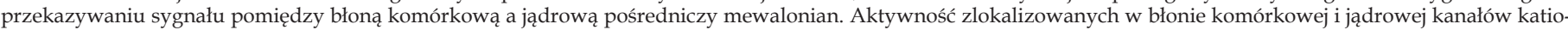

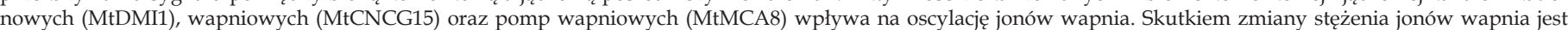

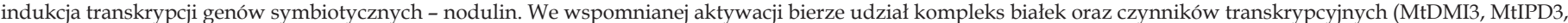
MtNSP1, MtNSP2, DELLA).

okulacji symbiontami oraz infekcji patogenami znacznie ułatwia prace eksperymentalne na omawianym modelu roślinnym. Analizę funkcjonalną genów M. truncatula umożliwiają liczne populacje mutantów [17]. Tworzone są mapy genetyczne oraz biblioteki cDNA. Ponadto, w celu ułatwienia badań nad oddziaływaniami biotyczny$\mathrm{mi}$, zarówno symbiotycznymi jak i patogennymi, powstało wiele narzędzi transkryptomicznych, proteomicznych i metabolomicznych. Dostępne są platformy bioinformatyczne z danymi uzyskanymi z doświadczeń na mikromacierzach, jak również pochodzącymi z sekwencjonowania RNA (RNA-seq, ang. RNA sequencing), mapami referencyjnymi badań proteomicznych oraz bibliotekami badań metabolicznych [17].

Ze względu na cechy rośliny modelowej oraz zdolność do nawiązywania oddziaływań biotycznych, zarówno z bakteriami korzeniowymi, grzybami mikorytycznymi oraz patogenami, $M$. truncatula stanowi odpowiedni model do badań genetycznych rodziny Fabaceae.

\section{PRZEBIEG PROCESU INFEKCJI KORZENIA PRZEZ RIZOBIA ORAZ MORFOGENEZA BRODAWKI KORZENIOWEJ}

Zjawisko współdziałania roślin bobowatych i bakterii symbiotycznych, prowadzące do powstania brodawek korzeniowych, jest procesem wieloetapowym, specyficznym i precyzyjnie regulowanym.

\section{WCZESNE FAZY PROCESU INFEKCJI}

Wymiana chemicznych sygnałów pomiędzy partnerami symbiotycznymi stanowi pierwszy krok inicjujący nawiązanie symbiotycznych interakcji. W warunkach niedoboru azotu, roślina wydziela do ryzosfery flawo- noidy, o charakterze chemoatraktantów. Indywidualne flawonoidy są rozpoznawane przez określone gatunki rizobiów, determinując tym samym specyficzność procesu [19]. Pochodzące od makrosymbionta molekuły sygnałowe aktywują bakteryjny regulator transkrypcyjny NodD, wykazujący zdolność do wiązania konserwatywnych motywów DNA, tzw. sekwencji nod-box. Białko NodD pod wpływem flawonoidów indukuje transkrypcję genów nod (ang. nodulation), odpowiedzialnych za syntezę bakteryjnych cząstek sygnałowych - czynników Nod (NF, ang. Nod Factor) (Ryc. 1a) [20]. Czynniki Nod są to lipochitooligosacharydy, których struktura szkieletu N-acetyloglukozaminowego jest wspólna dla większości rizobiów [21]. Specyficzność wobec gatunków roślin gospodarzy jest determinowana poprzez różnice w długości szkieletu głównego (od 3-5 jednostek cukrowych) oraz rodzaj jego modyfikacji obejmujących, m.in. sulfidyzację, acetylację, fukozylację oraz glikozylację [22]. Funkcje sygnałowe w procesie brodawkowania pełnią również, oprócz czynnika Nod, bakteryjne polisacharydy powierzchniowe, m.in.: lipopolisacharydy (LPS, ang. Lipopolysaccharide), egzopolisacharydy (EPS, ang. Exopolysaccharide), cykliczne $\beta$-glukany oraz kapsularne polisacharydy (CPS, ang. Capsular Polysaccharides). Rozpoznawanie struktur powierzchniowych mikrosymbionta przez roślinne receptory stanowi kolejny element decydujący o specyficzności gatunkowej partnerów symbiotycznych. Ponadto, bakteryjne polisacharydy powierzchniowe funkcjonują jako supresory odpowiedzi obronnej roślin, umożliwiając rozwój i ustabilizowanie się efektywnej symbiozy [23].

W percepcji bakteryjnego sygnału pośredniczą roślinne receptory czynnika Nod (NFR, ang. Nod factor Receptor), zlokalizowane w błonie komórkowej włośników korzeniowych [21]. Badania prowadzone z wykorzystaniem modelowych roślin bobowatych pozwoliły na identyfi- 
kację dwóch lizynowych receptorów kinazowych, które tworząc ze sobą kompleksy (LjNFR1/LjNFR5 u Lotus japonicus; MtLYK3/MtNFP u Medicago truncatula), odpowiadają za percepcję czynnika Nod i transdukcję sygnału (Ryc. 1b) [20,22]. W efekcie dochodzi do pulsacyjnej zmiany wewnątrzkomórkowego stężenia jonów wapnia $\left(\mathrm{Ca}^{2+}\right)$ (ang. calcium spiking) [3]. Percepcja czynnika Nod aktywuje tzw. wspólny symbiotyczny szlak sygnałowy (ang. common symbiosis signaling pathway). Aktywatorami szlaku, oprócz wspomnianych receptorów NFR, są oddziałujące z nimi, kinazy białkowe LjSYMRK/MtDMI2, należące do podrodziny LRR-RLK (ang. Leucine Rich Repeat Receptor-Like Kinase). Komponentami szlaku, wpływającymi bezpośrednio na oscylacje jonów wapnia są zlokalizowane w błonie komórkowej oraz błonie otoczki jądrowej kanały kationowe (LjCASTOR, LjPOLLUX, MtDMI1), wapniowe (MtCNGC15), jak również pompy wapniowe (MtMCA8). Niedawne doniesienia sugerują, iż w przekazywaniu sygnału pomiędzy błoną komórkową, w której zlokalizowane są kinazowe receptory a błoną jądrową, zawierającą wspomniane kanały i pompy, pośredniczy produkt szlaku mewalonowego - mewalonian (Ryc. 1b) [22,24]. W odpowiedzi na oscylacje jonów wapnia dochodzi do aktywacji w nukleoplazmie, kinazy białkowej LjCCaMK/MtDMI3, która następnie fosforyluje transkrypcyjny aktywator, białko LjCYCLOPS/MtIPD3. Przypuszcza się, iż LjCYCLOPS/MtIPD3 stanowi element większego kompleksu, zawierającego czynniki transkrypcyjne GRAS (NSP1, NSP2, DELLA) (Ryc. 1b). Wspomniany kompleks indukuje ekspresję genów symbiotycznych, tzw. nodulin (m.in. ENOD11) oraz szeregu czynników transkrypcyjnych (m.in. NIN), które pełnią istotną rolę w aktywacji dwóch równoległych programów rozwojowych w ryzodermie i korze pierwotnej $[20,22]$.

\section{WNIKANIE BAKTERII DO WNĘTRZA KORZENIA}

W efekcie percepcji czynnika Nod przez roślinne receptory i transdukcji sygnału w ryzodermie, specyficzne dla gospodarza bakterie symbiotyczne wnikają do wnętrza korzenia [25].

Jednym z najlepiej poznanych sposobów infekcji, występującym u większości roślin bobowatych, m.in. u lucerny, komonicy, grochu, oraz fasoli, jest formowanie tzw. nici infekcyjnych w rozwijających się włośnikach korzeniowych [26]. Do najbardziej podatnych na infekcje włośników, należą te, które niedawno zakończyły wzrost [27]. Aktywacja wspólnego symbiotycznego szlaku sygnałowego w ryzodermie prowadzi do lokalnego zahamowania wzrostu wierzchołka włośnika i jego skręcenia. Otoczone włośnikiem bakterie wnikają do jego wnętrza poprzez lokalną hydrolizę ściany komórkowej i inwaginację błony cytoplazmatycznej rośliny. Bakterie dzieląc się tworzą kolonie, tzw. ogniska infekcji (ang. infection foci), z których rozwijają się wewnątrzkomórkowe, tubularne struktury - nici infekcyjne (IT, ang. Infection Thread) [3]. W przylegających do zainfekowanych włośników, komórkach kory pierwotnej dochodzi do rearanżacji cytoszkieletu. Jądro oraz cytoplazma komórek kory zmieniają położenie z części peryferycznych ku środkowi, czemu towarzyszy fragmentacja wakuoli. Powstałe tym samym pasma cytoplazmy, bogate w mikrotubule, tworzą tzw. nici preinfekcyjne (PIT, ang. Pre-infection Thread), wyznaczając kierunek przemieszczającej się do zawiązka brodawki nici infekcyjnej [28].

\section{POWSTANIE ZAWIAZZKA BRODAWKI KORZENIOWEJ}

Równolegle do kaskady sygnałowej czynnika Nod $\mathrm{w}$ ryzodermie, w komórkach kory pierwotnej, pod jego wpływem, dochodzi do formowania zawiązka brodawki korzeniowej. Biorąc pod uwagę fakt, iż czynnik Nod nie jest mobilną molekułą oraz fakt, iż w momencie aktywacji podziałów komórkowych kory, bakterie syntetyzujące NF, znajdują się na lub w ryzodermie, postuluje się istnienie zależnego od NF mobilnego sygnału łączącego odpowiedź ryzodermalną i kortykalną [29,30]. Jednakże, natura biochemiczna wspomnianego sygnału nie została jak dotąd zweryfikowana.

Pod względem morfologicznym i anatomicznym wyróżniamy dwa typy brodawek. Brodawki niezdeterminowane posiadają trwale funkcjonujący merystem, cylindryczny kształt, gradientowe strefy rozwojowe oraz są formowane w większości przez rośliny bobowate klimatu umiarkowanego, m.in. Pisum sativum oraz Medicago truncatula. W przypadku brodawek zdeterminowanych, aktywność komórek merystematycznych zostaje zahamowana, kiedy brodawki osiągną określoną wielkość. Brodawki o wzroście ograniczonym mają kształt kolisty, nie wykazują gradientu rozwojowego oraz są produkowane przez rośliny bobowate klimatu tropikalnego, m.in. Glycine max oraz Lotus japonicus [27].

W zależności od gatunku makrosymbionta oraz typu powstającej brodawki różne warstwy komórek korzenia są zaangażowane w jej zainicjowanie. Modelem roślinnym, w którym proces morfogenezy brodawki został najlepiej poznany jest $M$. truncatula $[28,30]$. W przeciwieństwie do roślin wykształcających brodawki o wzroście ograniczonym, u M. truncatula zawiązek (primordium) brodawki zlokalizowany jest w obrębie kory wewnętrznej. Jego formowanie rozpoczynają antyklinalne (poprzeczne) podziały komórek perycyklu, znajdującego się naprzeciw wiązek protoksylemu. Podziały mitotyczne stopniowo obejmują wewnętrzne warstwy kory pierwotnej oraz endodermę. W późniejszych etapach aktywne mitotycznie komórki ulegają podziałom peryklinalnym (równoległym) w kierunku wzrastającej nici infekcyjnej, dając początek merystemowi (środkowe warstwy kory) oraz wiązkom przewodzącym brodawki (endoderma i perycykl). W odróżnieniu od merystemu brodawek zdeterminowanych, merystem brodawek niezdeterminowanych nie podlega infekcji. W wyniku jego stałych podziałów dochodzi do różnicowania komórek, w których po zasiedleniu przez mikrosymbionta asymilowany jest azot. Komórki podlegające inicjalnej kolonizacji przez bakterie, które uwalniane są z nici infekcyjnej, powstają z podziałów wewnętrznych warstw kory [28,30].

Zrozumienie genetycznych mechanizmów regulacji, leżących u postaw opisanych zdarzeń, zachodzących w wewnętrznych warstwach korzenia, stanowi jedno z kluczo- 
wych wyzwań, pojawiających się w badaniach procesów symbiotycznych. Postuluje się, iż kluczową rolę w modulacji podziałów komórkowych prowadzących do morfogenezy brodawki odgrywają hormony roślinne.

\section{FORMOWANIE I ROLA SYMBIOSOMÓW}

Końcowy etap procesu infekcji stanowi endocytoza komórek bakteryjnych z nici infekcyjnych do komórek strefy zakażenia zawiązka brodawki korzeniowej [31]. Uwolnienie rizobiów następuje $\mathrm{w}$ tzw. kroplach infekcyjnych (ang. infection droplets), powstałych z nieotoczonego ścianą komórkową, wierzchołkowego fragmentu nici infekcyjnej. W zasiedlanych komórkach bakterie oddzielone są od cytoplazmy błoną peribakteroidalną pochodzenia roślinnego, tworząc symbiosomy - struktury podobne do organellum. Wewnątrz symbiosomów dochodzi do podziałów i różnicowania wegetatywnych form rizobiów W wiążące azot bakteroidy. W przypadku roślin z grupy IRLC, do których należy Medicago truncatula, różnicowanie bakteroidów jest terminalne, czego oznaką jest m.in. zwiększenie rozmiarów symbiosomów, zwielokrotnienie genomu, przy jednoczesnym zahamowaniu podziałów bakterii (endoreduplikacja), oraz utrata zdolności do reprodukcji. Wykazano, iż specyficzne dla brodawek, bogate w cysteinę białka roślinne (NCR, ang. Nodule-specific Cysteine-Rich) wymuszają terminalną dyferencjację bakteroidów, czyniąc proces wiązania azotu bardziej wydajnym [32,33]. Redukcja azotu cząsteczkowego do amoniaku stanowi kosztowny pod względem energetycznym proces, zachodzący za pośrednictwem kompleksu enzymatycznego nitrogenezy. Jak wspomniano wcześniej, nitrogenaza jest enzymem wrażliwym na działanie tlenu, który prowadzi do jej nieodwracalnego uszkodzenia. Główną rolą rozwijającej się brodawki jest więc zapewnienie środowiska mikroaerobowego, pozwalającego na syntezę ATP, przy jednoczesnej ochronie nitrogenazy przed toksycznym działaniem tlenu. Środowisko mikroaerofilne jest tworzone m.in. poprzez: (i) wykształcenie bariery dyfuzyjnej dla tlenu $\mathrm{w}$ parenchymie brodawki, oraz (ii) aktywność leghemoglobiny, regulującej dostępność tlenu dla bakteroidów [34]. W wymianie zredukowanych związków azotu i kwasów dikarboksylowych pochodzących z fotosyntezy, pośredniczy błona peribakteroidalna symbiosomu. $\mathrm{W}$ zależności od typu brodawki korzeniowej zredukowany azot jest z niej eksportowany $\mathrm{w}$ formie amidowej (brodawki niezdeterminowane) lub ureidowej (brodawki zdeterminowane) [34].

\section{ROLA CYTOKININ W MORFOGENEZIE BRODAWKI}

Nawiązanie efektywnej symbiozy pomiędzy rośliną a mikrosymbiontem wymaga zapoczątkowania dwóch procesów rozwojowych, odpowiednio w ryzodermie oraz w znajdujących się pod nią komórkach kory pierwotnej. Pomimo, iż infekcja bakteryjna jak i formowanie zawiązka brodawki korzeniowej wydają się być niezależne oraz są tkankowo i genetycznie rozdzielone, ich inicjacja jest zsynchronizowana, co może sugerować ścisną regulację i koordynację obu procesów $[25,35]$. Jednakże, molekularne mechanizmy łączące ścieżkę sygnałową czynnika Nod w ryzodermie oraz aktywację podziałów mitotycznych $\mathrm{w}$ korze pierwotnej pozostają niewyjaśnione [36]. Rosnąca liczba dowodów naukowych wskazuje na istotną rolę hormonów roślinnych, szczególnie cytokinin, $\mathrm{w}$ modulacji oddziaływań symbiotycznych, zarówno na początkowych jak i późniejszych etapach brodawkowania.

\section{BIOSYNTEZA I PRZEMIANY METABOLICZNE CYTOKININ IZOPRENOWYCH}

Naturalnie występujące $\mathrm{w}$ roślinach cytokininy stanowią pochodną adeniny, zawierającą izoprenowy łańcuch alifatyczny lub rzadziej, aromatyczny podstawnik benzylowy, w pozycji $\mathrm{N}^{6}$ pierścienia purynowego. Należące do cytokinin izoprenowych: $\mathrm{N}^{6}$-( $\Delta^{2}$-izopentenylo $)$ adenina (iP) oraz trans-Zeatyna $(t Z)$ stanowią grupę najliczniej obecnych w roślinach cytokinin [37]. Wśród form izoprenowych wyróżnić można: (i) aktywne biologicznie wolne zasady, (ii) nukleozydy (rybozydy), (iii) O- i N-glikozydy, oraz (iv) nukleotydy (rybotydy). Homeostaza aktywnych biologicznie cytokinin jest czasowo oraz przestrzennie regulowana poprzez enzymy zaangażowane $\mathrm{w}$ ich biosyntezę, modyfikację oraz degradację [38].

Pierwszym etapem biosyntezy de novo cytokinin izoprenowych (iP, $t Z$ ) jest przyłączenie łańcucha izopentenylowego, pochodzącego z a, adimetyloallilopirofosforanu (DMAPP), do azotu $\mathrm{N}^{6}$ grupy aminowej nukleotydów adeninowych (AMP, ADP lub ATP). Wspomnianą reakcję katalizują enzymy - transferazy izopentenylowe (IPT, ang. Isopentenyltransferase), które u Arabidopsis thaliana zlokalizowane są w cytoplazmie, mitochondrium, oraz plastydach. Roślinne białka IPT wykorzystują preferencyjnie ADP oraz ATP jako akceptory łańcucha izopentenylowego [38]. Defosforylację powstałych dzięki aktywności IPT rybotydów iP umożliwiają fosfatazy [39]. Rybotydy iP, w szczególności izopentenylo-ADP oraz izopentenylo-AMP, mogą następnie zostać przekształcone do rybotydów $t Z$ poprzez hydroksylację izopentenylowego łańcucha bocznego. Katalizatorami reakcji są monooksygenazy cytochromu P450 (CYP735A1 oraz CYP735A2). Bezpośrednia konwersja nieaktywnych biologicznie rybotydów iP oraz $t Z$ do wolnych zasad, polegająca na usunięciu reszt rybozy, jest możliwa dzięki aktywności fosforybohydrolaz LOG (ang. Lonely Guy). U A. thaliana ich przedstawiciele zostali zlokalizowani w cytoplazmie oraz jądrze [38].

Istotny czynnik regulujący poziom cytokinin izoprenowych stanowi ich nieodwracalna degradacja, katalizowana przez dehydrogenazy/oksydazy cytokinin (CKX, ang. Cytokinin Dehydrogenase/Oxidase). Aktywność CKX prowadzi do odłączenia łańcucha alifatycznego od pierścienia purynowego, co skutkuje wyodrębnieniem adeniny [40]. U A. thaliana enzymy degradujące cytokininy zlokalizowane są zarówno w apoplaście, cytoplazmie, jak i wakuoli [38]. W modulacji aktywności cytokinin ważną rolę odgrywa również glukozylacja. Wspomniana metaboliczna inaktywacja może być: (i) odwracalna (O-glukozylacja łańcucha bocznego zeatyny) oraz (ii) nieodwracalna (N-glukozylacja w pozycji $\mathrm{N}^{7}$ lub $\mathrm{N}^{9}$ ), a glukozylowane formy cytokinin są magazynowane $\mathrm{w}$ wakuoli [40]. W inaktywacji cytokinin pośredniczy również fosforybozylo- 


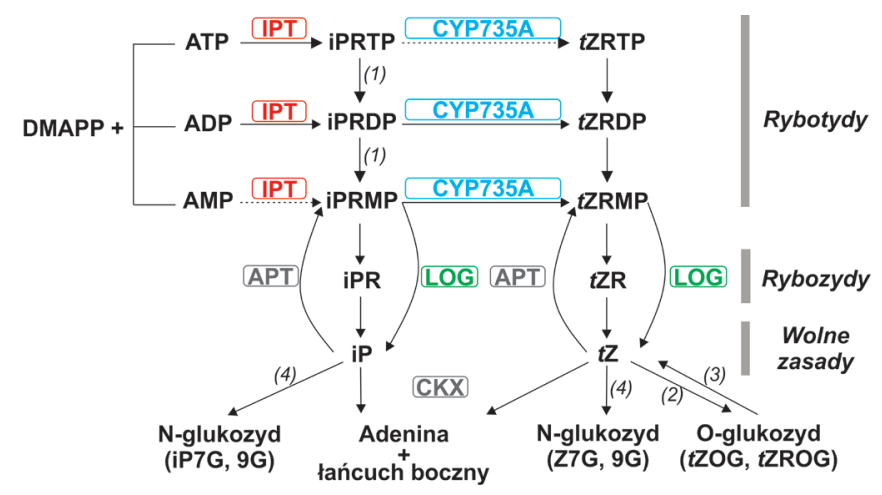

Rycina 2. Uproszczony model biosyntezy, inaktywacji oraz degradacji cytokinin izoprenowych. Transferazy izopentenylowe (IPT) katalizują przyłączenie, pochodzącego z DMAPP, łańcucha izopentenylowego, do nukleotydów adeninowych. Defosforylację rybotydów iP (iPRTP oraz iPRDP) umożliwiają fosfatazy (1). W konwersji rybotydów iP do rybotydów $t Z$ pośredniczą monooksygenazy cytochromu P450 (CYP735A1/A2). Fosforybohydrolaza (LOG) bierze udział w bezpośredniej konwersji rybotydów iP oraz $t Z$ do biologicznie aktywnych wolnych zasad. W przekształceniu wolnych zasad do rybotydów pośredniczy fosforybozylotransferaza adeninowa (APT). Dehydrogenazy/oksydazy cytokinin (CKX) katalizują odłączenie łańcucha alifatycznego od pierścienia purynowego, czego efektem jest nieodwracalna degradacja cytokinin. $t Z$ może zostać odwracalnie przekształcona do O-glukozydu przez O-glukozylotransferazę zeatyny (2) i $\beta$-glukozydazę.(3). Nieodwracalna N-glukozylacja jest katalizowana przez N-glukozylotransferazę cytokinin (CK-N-GT) (4). Linią nieprzerywaną oznaczono preferencyjne substraty dla odpowiednich enzymów.

transferaza adeninowa (APT, ang. Adenine Phosphoribosyl Transferase), przekształcając wolne zasady do rybotydów [41]. Rycina 2 przestawia opisany, uproszczony szlak biosyntezy i metabolizmu cytokinin izoprenowych.

\section{PERCEPCJA I TRANSDUKCJA SYGNAŁU CYTOKININOWEGO W KOMÓRCE}

Cytokininy stanowią grupę regulatorów wzrostu i rozwoju, stymulujących podziały oraz różnicowanie się komórek [38]. Wpływ wspomnianych fitohormonów na rozwój oraz fizjologię rośliny wynika głównie z regulacji ekspresji genów [40]. Transdukcja sygnału cytokininowego do genów docelowych jest możliwa dzięki wieloetapowemu systemowi fosforylacji, znanemu jako TCS (ang. Two-Component System). Składa się on z trzech grup białek: (i) błonowych receptorów, należących do rodziny kinaz histydynowych HK (ang. His Kinase), (ii) białek fosfotransferowych zawierających histydynę (HP, ang. His-containing Phosphotransfer Proteins) oraz (iii) jądrowych regulatorów odpowiedzi typu B (RR-B, ang. Response Regulator type B). Percepcja biologicznie aktywnych cytokinin (iP, $t Z$ ) przez białko receptorowe, indukuje jego autofosforylację. Następnie w translokacji grupy fosforanowej z cytoplazmy do jądra pośredniczy białko fosfotransferowe. Ostatecznie ufosforylowane regulatory odpowiedzi typu B wiążą się do docelowego DNA, zawierającego motyw $5^{\prime}-(\mathrm{A} / \mathrm{G}) \mathrm{GAT}(\mathrm{C} / \mathrm{T})-3^{\prime}$, inicjując transkrypcję genów, zaangażowanych we wczesną odpowiedź na cytokiny (Ryc. 3). W regulacji szlaku sygnałowego cytokinin na zasadzie ujemnego sprzężenia zwrotnego biorą udział indukowane przez RR-B, regulatory odpowiedzi typu A (RR-A) [40,42,43].

U Arabidopsis thaliana, receptory cytokinin są zlokalizowane zarówno w błonie komórkowej, jak również błonie

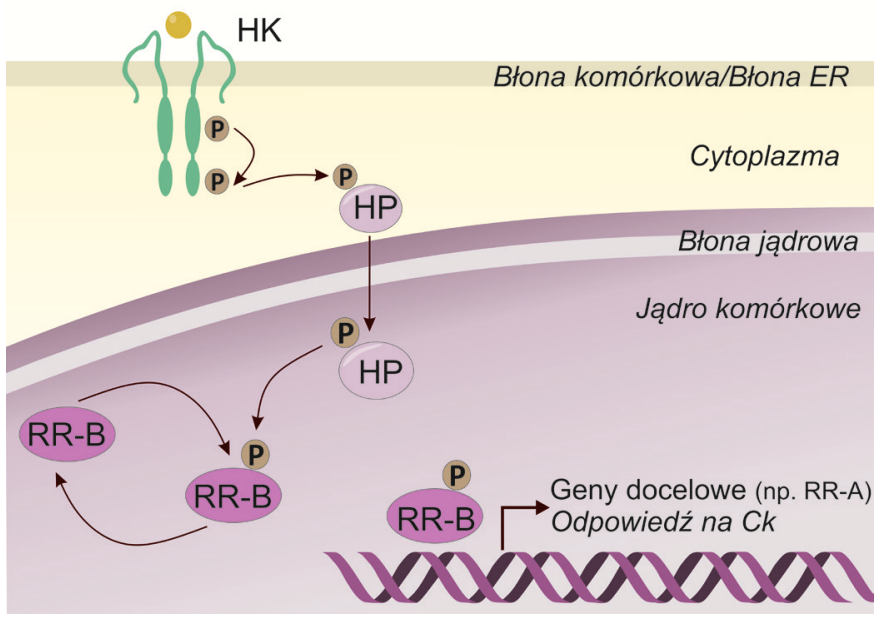

Rycina 3. Percepcja i transdukcja sygnału cytokininowego w komórce. Percepcja aktywnych biologicznie form cytokinin przez zlokalizowany w błonie komórkowej lub błonie retikulum receptor $\mathrm{HK}$, prowadzi do jego autofosforylacji. Białka fosfotransferowe (HP) pełnią funkcję przenośnika grupy fosforanowej pomiędzy receptorem cytokinin a jądrowymi regulatorami odpowiedzi typu B (RR-B). Ufosforylowane RR-B wiążą się do promotora genów docelowych (w tym RR-A), indukujących ich transkrypcję.

retikulum endoplazmatycznego (ER). Jednakże, nadal nie wiadomo, która z wymienionych lokalizacji stanowi dominujące miejsce percepcji sygnału cytokininowego [44]. Ostatnio opublikowane dane dotyczące oddziaływań in planta receptorów cytokinin z białkami fosfotransferowymi wskazują na wewnątrzkomórkową lokalizację ścieżki sygnałowej cytokinin [45]. Analizy lokalizacji znakowanego fluorescencyjnie białka AtCKX1, należącego do dehydrogenaz/oksydaz cytokinin, sugerują, iż retikulum endoplazmatyczne jest ponadto głównym miejscem ich degradacji [46]. Pomimo przedstawionych argumentów rola błony komórkowej w kaskadzie sygnałowej cytokinin nie może zostać wykluczona. Badania dotyczące zlokalizowanego w błonie komórkowej białka importującego cytokininy (AtPUP14) pokazały, iż może brać on udział w hamowaniu percepcji cytokinin przez receptor. Udowodniono ponadto, iż degradacja cytokinin pochodzenia apoplastycznego hamuje odpowiedź komórek na ten fitohormon [47].

\section{ŚCIEŻKA SYGNAŁOWA CYTOKININ W KORZE PIERWOTNEJ A FORMOWANIE PRIMORDIUM BRODAWKI U MEDICAGO TRUNCATULA}

Aktywacja ścieżki sygnałowej cytokinin w korze pierwotnej stanowi kluczowy proces, niezbędny do powstania zawiązka brodawki korzeniowej oraz nawiązania wydajnej symbiozy. U Medicago truncatula proces percepcji oraz transdukcji sygnału cytokininowego jest zależy od białka receptorowego MtCRE1/MtHK1 (ang. Cytokinin Response 1, His Kinase 1). Jego dysfunkcja skutkuje, m.in. istotnym obniżeniem liczby powstających brodawek oraz zaburzeniem $73 \%$ zmian transkrypcyjnych indukowanych przez czynnik Nod [48-51].

W efekcie aktywacji zależnej od MtCRE1 kaskady sygnałowej, dochodzi do transkrypcji genów zaangażowa- 
nych w biosyntezę cytokinin (MtCYP735A1), ich aktywację (MtLOG3), odpowiedź (MtRRA4), degradację (MtCKX2, $M t C K X 3)$ oraz inaktywacje (MtAPT1, MtAPT2). W konsekwencji, biologicznie aktywne cytokininy (iP oraz $t Z$ ) sac biosyntetyzowane oraz akumulowane w strefie korzenia podatnej na infekcje rizobiami (ang. root susceptible zone). Fakt, iż akumulacja cytokinin nie jest obserwowana w roślinach z mutacją w obrębie genu, kodującego kinazę białkową CCaMK/MtDMI3, sugeruje zależność tego procesu od kaskady sygnałowej czynnika Nod [50]. Biosynteza de novo cytokinin oraz zwiększona na nie odpowiedź komórek kory pierwotnej może stanowić cześć pozytywnego sprzężenia zwrotnego, skutkującego rozprzestrzenianiem się sygnału cytokininowego, podziałami mitotycznymi komórek kory oraz morfogenezą brodawki. We wspomnianym zwiększaniu się odpowiedzi komórek na fitohormon bierze również udział jeden z czynników transkrypcyjnych aktywowanych podczas transdukcji sygnału cytokininowego. Pokazano, iż czynnik transkrypcyjny NIN może wiązać się bezpośrednio do promotora genu MtCRE1 i indukować jego ekspresję w komórkach kory pierwotnej [52]. Jednakże, molekularny mechanizm odpowiedzialny za zapoczątkowanie omawianej kaskady sygnałowej, przez nieznaną cząstkę sygnałową, wymaga wyjaśnienia.

Regulacja cyklu komórkowego, a tym samym podziałów mitotycznych komórek jest zależna od gradientu stężeń auksyn oraz cytokinin. Obecność wspomnianych fitohormonów ma wpływ na transkrypcję genów cyklu komórkowe- go, tzw. cyklin (CYC, ang. Cyclin) oraz zależnych od cyklin kinaz (CDK, ang. Cyclin-Dependent Kinase) [53]. U M. truncatula, egzogenna aplikacja auksyn indukuje ekspresję genu, kodującego cyklinę typu A (cycA2;2), należącą do grupy cyklin mitotycznych. Analiza aktywności promotora genu cycA2;2 pod wpływem auksyn, wykazała, iż jest on aktywowany w dzielących się komórkach, znajdujących się naprzeciw wiązek protoksylemu, gdzie dochodzi do powstania zawiązka brodawki [53]. Zapoczątkowanie odpowiedzi komórek na auksyny podczas formowania primordium brodawki jest zależne od szlaku sygnałowego cytokinin [54]. Postuluje się, iż rola cytokinin w promowaniu podziałów komórkowych ma charakter pośredni, związany z modulacją polarnego transportu auksyn [28].

W warunkach niesymbiotycznych, w korzeniu auksyny (IAA, ang. Indole-3Acetic Acid) transportowane są akropetalnie w kierunku jego wierzchołka, przez wiązki przewodzące oraz bazypetalnie ( $\mathrm{z}$ wierzchołka korzenia do jego strefy elongacyjnej) zewnętrznymi warstwami korzenia [55]. We wspomnianej translokacji pośredniczą eksportery auksyn, białka PIN. Inokulacja mikrosymbiontem inicjuje zmiany $\mathrm{w}$ polarnym transporcie fitohormonu. W wyniku zależnej od MtCRE1, biosyntezy i aktywności flawonoidów (m.in. naringeniny, izolikwiritigeniny oraz kaempferolu) dochodzi do zahamowania akropetalnej translokacji auksyn poniżej miejsca infekcji, przy jednoczesnym zwiększeniu transportu bazypetalnego oraz ich akumulacji w miejscu przyszłego zawiązka brodawki (Ryc. 4) [55].

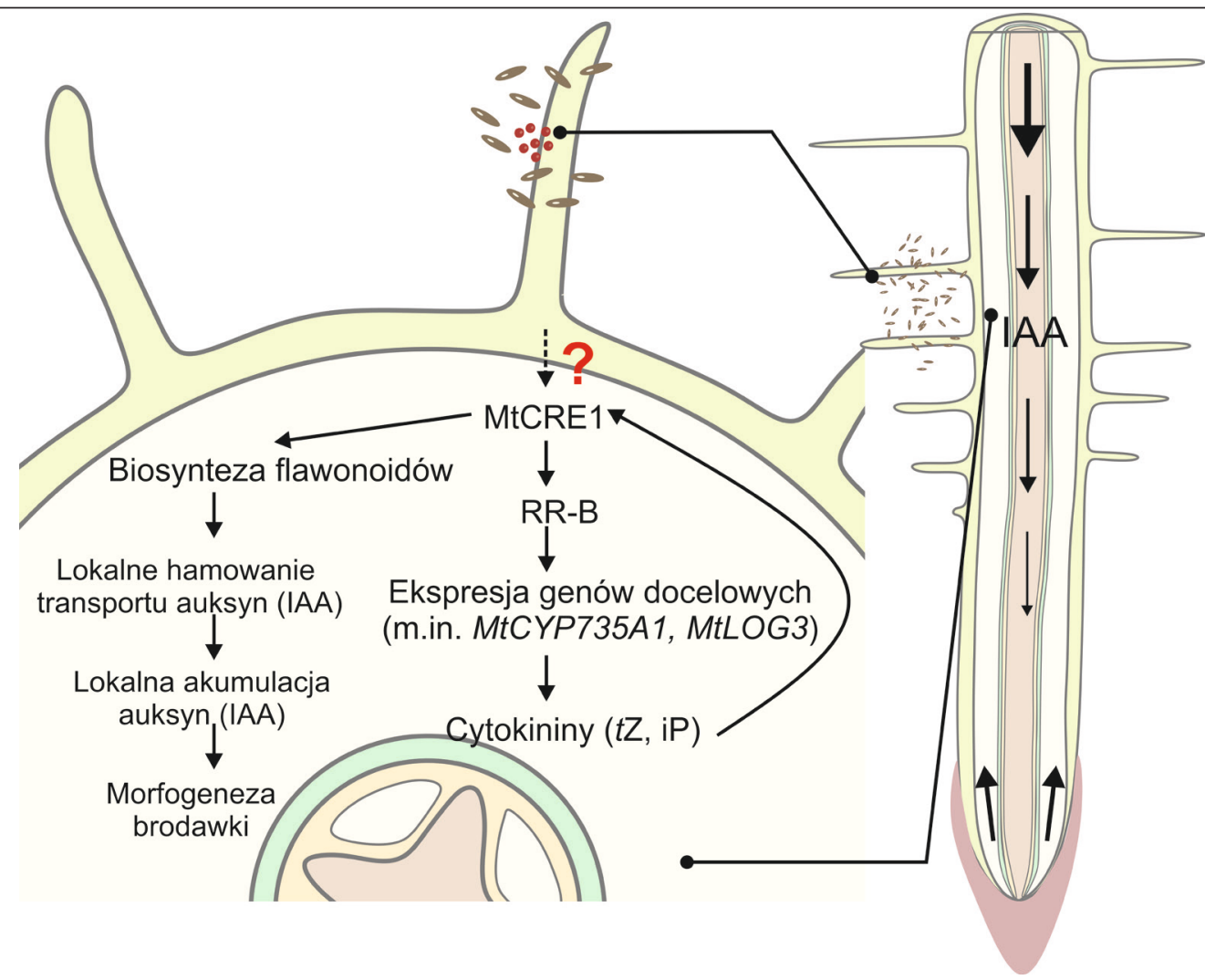

Rycina 4. Schematyczne przedstawienie kaskady sygnałowej cytokinin w korze pierwotnej.

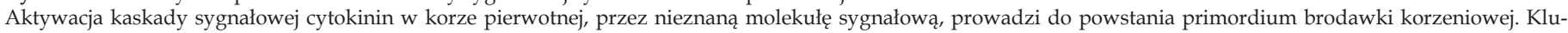

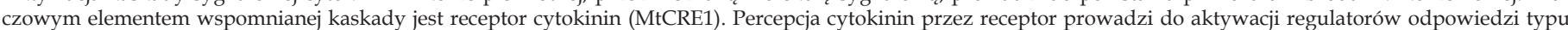

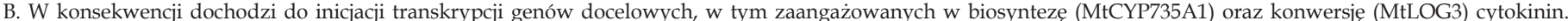

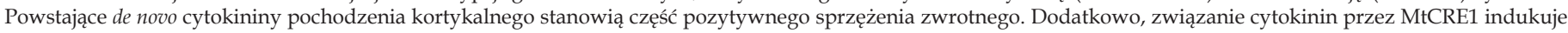

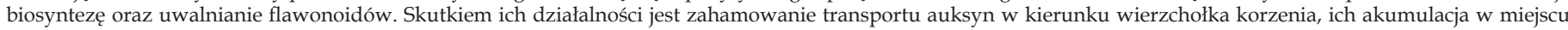
infekcji, podziały komórkowe i morfogeneza brodawki. 
CYTOKININY POCHODZENIA RYZODERMALNEGO ORAZ ICH ROLA PODCZAS BRODAWKOWANIA U MEDICAGO TRUNCATULA

Jak opisano wcześniej, cytokininy pełnią pozytywną rolę $\mathrm{w}$ regulacji powstawania zawiązka brodawki korzeniowej, stymulując podziały perycyklu, endodermy oraz kory pierwotnej. Przez długi czas zakładano, iż inicjacja ścieżki sygnałowej cytokinin, zależnej od czynnika Nod, oraz pierwsza odpowiedź rośliny na ten fitohormon zachodzi w komórkach kory pierwotnej. Jednakże, ostatnio opublikowane, tkankowo-specyficzne analizy transkryptomu Medicago truncatula wykazały wczesną aktywację kaskady sygnałowej cytokinin w ryzodermie $[36,56]$. Egzogenna aplikacja czynnika Nod skutkowała indukcją ekspresji genów w komórkach ryzodermalnych, zaangażowanych zarówno w inicjację biosyntezy cytokinin (MtKNOX3), ich biologiczną aktywację (MtLOG1) oraz przekształcenie (MtCYP735A1), percepcję (MtCRE1), odpowiedź (m.in MtRRA2, MtRRA8, MtRRA9), jak również degradację (m.in. MtCKX1, MtCKX2) [36]. Co więcej, zaobserwowano akumulację nieaktywnych biologicznie, nukleotydowych prekursorów cytokinin, tj. tZRP, iPRP w tkance okrywającej korzeń. Fakt ten może być interesujący ze względu na to, iż fosforybohydrolaza (MtLOG1), katalizująca konwersję nukleotydowych prekursorów w aktywne biologicznie wolne zasady, jest zlokalizowana w obrębie ryzodermy [36]. Dodatkowym argumentem na to, iż zależna od NF odpowiedź komórek na cytokininy zachodzi $\mathrm{w}$ pierwszej kolejności $\mathrm{w}$ ryzodermie, a następnie w korze pierwotnej, były wyniki uzyskane przy pomocy syntetycznego systemu reporterowego dla obecności cytokinin (TCSn, ang. Two Component Sensor new) [36]. System TCSn składa się z konstrukcji genowej zawierającej serię powtórzonych elementów cis, znajdujących się w promotorach genów zaangażowanych we wczesną odpowiedź na cytokininy. Umożliwia to monitorowanie aktywacji transkrypcji w odpowiedzi na ten bodziec hormonalny [43]. Taki sztuczny promotor powiązany został z genem reporterowym GUS. Po kilku godzinach od inokulacji mikrosymbiontem sygnał TCSn:GUS obserwowano w obrębie ryzodermy i zewnętrznych warstw kory. Po dwóch dniach od infekcji sygnał ten rozprzestrzenił się na wewnętrzne warstwy kory pierwotnej [36].

W przeciwieństwie do udokumentowanej roli cytokinin w odpowiedzi kortykalnej i formowaniu primordium brodawki, funkcja cytokinin pochodzenia ryzodermalnego nie jest wyjaśniona. Biorąc pod uwagę, ich obecność w ryzodermie oraz następującą po sobie aktywację odpowiedzi komórek w tkance okrywającej oraz korze, ryzodermalne cytokininy mogą pełnić rolę mobilnego sygnału, integrującego zewnętrzną i wewnętrzną odpowiedź tkanki korzeniowej na infekcję rizobiami. Percepcja cytokinin pochodzenia ryzodermalnego przez zlokalizowany w komórkach kory receptor MtCRE1 prowadziłaby do zainicjowania ich szlaku sygnałowego. Jak opisano wcześniej, następstwem aktywacji kaskady sygnałowej jest biosynteza de novo cytokinin oraz rozszerzanie się odpowiedzi komórek na ten fitohormon $\mathrm{w}$ wewnętrznych warstwach korzenia, skutkujące uformowaniem zawiązka brodawki. Co ciekawe, czynnik Nod indukuje ekspresję zlokalizowanych w ryzodermie genów, należących do rodzin, zaproponowanych jako zaangażowane w translokację cytokinin [36]. Jednakże, jak do tej pory żaden transporter cytokinin nie został zidentyfikowany i scharakteryzowany u roślin bobowatych.

\section{ROLA CYTOKININ JAKO NEGATYWNYCH REGULATORÓW PROCESU MORFOGENEZY BRODAWKI}

Biorąc pod uwagę fakt, iż brodawkowanie stanowi kosztowny pod względem energetycznym proces, liczba powstających brodawek jest ograniczana przez roślinę gospodarza do ilości niezbędnej dla zapewnienia optymalnego wzrostu [57]. Postuluje się, iż w negatywnej regulacji tego procesu mogą brać udział cytokininy. Wykazano, iż zależna od MtCRE1 ścieżka sygnałowa cytokinin w ryzodermie wpływa negatywnie na indukcję ekspresji genu MtENOD11. Mając na uwadze fakt, iż akumulowane pod wpływem czynnika Nod białko ENOD11 pełni istotną rolę zarówno w zainicjowaniu infekcji mikrosymbiontem jak i formowaniu zawiązka brodawki, jego ograniczenie za pomocą ryzodermalnych cytokinin może stanowić część negatywnego sprzężenia zwrotnego, hamującego kolejne infekcje [36]. Regulacja liczby powstających brodawek może mieć nie tylko charakter lokalny, ale również długodystansowy, polegający na komunikacji korzeń-pęd. Aktywacja autoregulacji brodawkowania (AON, ang. Autoregulation of Nodulation) podczas formowania się zawiązka brodawki jest zależna od kaskady sygnałowej cytokinin [58]. Pokazano, iż ekspresja genu MtCLE13, kodującego peptyd pełniący rolę molekuły sygnałowej, pośredniczącej w AON, jest zależna od MtCRE1 oraz MtNIN1 [59]. Co więcej, badania prowadzone na Lotus japonicus sugerują, iż pochodzące z korzenia peptydy CLE indukują biosyntezę cytokinin w częściach nadziemnych, które następnie wywierają negatywny wpływ na liczbę powstających brodawek [60].

\section{PODSUMOWANIE}

Współczesne procesy demograficzne prowadzące do wzrostu populacji ludzi na świecie wymagają poszukiwania rozwiązań dla zapewnienia bezpieczeństwa żywnościowego. Zwiększenie areału upraw związane jest ze wzrostem zapotrzebowania na azot $\mathrm{w}$ rolnictwie, co może prowadzić do zanieczyszczenia środowiska naturalnego. Jednym z istotnych wyzwań stojących przed współczesną agrobiotechnologią jest wykorzystanie potencjału biologicznego wiązania azotu w celu obniżenia sztucznego nawożenia. $\mathrm{W}$ ostatnich latach odnotowano znaczący postęp w zrozumieniu początkowych etapów interakcji symbiotycznych pomiędzy roślinami bobowatymi a rizobiami. Takich jak: (i) komunikacja partnerów symbiotycznych $\mathrm{w}$ ryzosferze, (ii) infekcja włośników korzenioniowych przez mikrosymbionta oraz (iii) tworzenie symbiotycznego organu - brodawki, wewnątrz tkanek korzenia. Obecnie, intensywne starania podejmowane są celem poznania kaskad regulatorowych integrujących wspomniane etapy, prowadzące do nawiązania efektywnej symbiozy. Postuluje się, iż kluczową rolę $\mathrm{w}$ modulacji podziałów komórkowych prowadzących do morfogenezy brodawki odgrywają hormony roślinne, głównie cytokininy. Jednakże, wciąż niepoznany jest molekularny mechanizm łączący ścieżkę sygnałową czynnika Nod w ryzodermie z aktywacją podziałów komórkowych $\mathrm{w}$ korze pierwotnej. Poznanie molekularnych mechanizmów 
regulujących proces symbiozy i biologicznego wiązania azotu może w przyszłości posłużyć m.in. do: (i) zwiększenia efektywności asymilacji azotu, (ii) rozwinięcia nowych układów symbiotycznych pomiędzy asymilatorami $\mathrm{N}_{2}$ a roślinami o dużym znaczeniu gospodarczym, (iii) jak również zainicjowania zdolności wiązania azotu atmosferycznego przez organizmy eukariotyczne, w tym rośliny [2, 6, 61, 62].

\section{PIŚMIENNICTWO}

1. Andrews M, PJ Lea (2013) Our nitrogen 'footprint': the need for increased crop nitrogen use efficiency. Ann Appl Biol 163(2): 165-169

2. Oldroyd GE, R Dixon (2014) Biotechnological solutions to the nitrogen problem. Curr Opin Biotechnol 26: 19-24

3. Oldroyd GE, JD Murray, PS Poole, JA Downie (2011) The rules of engagement in the legume-rhizobial symbiosis. Annu Rev Genet 45: 119144

4. Fowler D, M Coyle, U Skiba, MA Sutton, JN Cape, i in. (2013) The global nitrogen cycle in the twenty-first century. Philosophical Transactions of the Royal Society B: Biological Sciences 368(1621)

5. Vitousek PM, DNL Menge, SC Reed, CC Cleveland (2013) Biological nitrogen fixation: rates, patterns and ecological controls in terrestrial ecosystems. Philosophical Transactions of the Royal Society B: Biological Sciences 368(1621)

6. Rogers C, GE Oldroyd (2014) Synthetic biology approaches to engineering the nitrogen symbiosis in cereals. J Exp Bot 65(8): 1939-1946

7. Bairoch A (2000) The ENZYME database in 2000. Nucleic Acids Res 28(1): 304-305

8. Santi C, D Bogusz, C Franche (2013) Biological nitrogen fixation in non-legume plants. Ann Bot 111(5): 743-767

9. Franche C, K Lindström, C Elmerich (2009) Nitrogen-fixing bacteria associated with leguminous and non-leguminous plants. Plant Soil 321(1): $35-59$

10. Kozłowski S, A Swędrzyński, W Zielewicz (2011) Rośliny motylkowate $\mathrm{w}$ środowisku przyrodniczym. Woda-Srodowisko-Obszary Wiejskie 11(4:36): 161-181

11. Geurts R, TT Xiao, B Reinhold-Hurek (2016) What Does It Take to Evolve A Nitrogen-Fixing Endosymbiosis? Trends Plant Sci 21(3): 199208

12. Walker R, CM Agapakis, E Watkin, AM Hirsch (2015) Symbiotic Nitrogen Fixation in Legumes: Perspectives on the Diversity and Evolution of Nodulation by Rhizobium and Burkholderia Species, W: de Bruijn F. (red), Biological Nitrogen Fixation. Wiley Blackwell, New Jersey, str.913-925

13. Sprent JI, J Ardley, EK James (2017) Biogeography of nodulated legumes and their nitrogen-fixing symbionts. New Phytol. 215(1): 40-56

14. Buchanan BB, W Gruissem, BL Russell (2015) Biochemistry and Molecular Biology of Plants. 2nd ed., Wiley, str.720-725

15. Azani N, M Babineau, CD Bailey, H Banks, AR Barbosa, i in. (2017) A new subfamily classification of the Leguminosae based on a taxonomically comprehensive phylogeny The Legume Phylogeny Working Group (LPWG). Taxon 66(1): 44-77

16. Pan H, D Wang (2017) Nodule cysteine-rich peptides maintain a working balance during nitrogen-fixing symbiosis. Nat Plants 3(5): 17048

17. Kang Y, M Li, S Sinharoy, J Verdier (2016) A Snapshot of Functional Genetic Studies in Medicago truncatula. Front Plant Sci 7: 1175

18. Tang H, V Krishnakumar, S Bidwell, B Rosen, A Chan, i in. (2014) An improved genome release (version Mt4.0) for the model legume Medicago truncatula. BMC Genomics 15: 312

19. Liu CW, JD Murray (2016) The Role of Flavonoids in Nodulation HostRange Specificity: An Update. Plants (Basel) 5(3):33

20. Limpens E, A van Zeijl, R Geurts (2015) Lipochitooligosaccharides modulate plant host immunity to enable endosymbioses. Annu Rev Phytopathol 53: 311-334
21. Nelson MS, MJ Sadowsky (2015) Secretion systems and signal exchange between nitrogen-fixing rhizobia and legumes. Frontiers in Plant Science 6(491)

22. Zipfel C, GE Oldroyd (2017) Plant signalling in symbiosis and immunity. Nature 543(7645): 328-336

23. Gourion B, F Berrabah, P Ratet, G Stacey (2015) Rhizobium-legume symbioses: the crucial role of plant immunity. Trends Plant Sci 20(3): 186-194

24. Venkateshwaran M, D Jayaraman, M Chabaud, A Genre, AJ Balloon, $i$ in. (2015) A role for the mevalonate pathway in early plant symbiotic signaling. Proceedings of the National Academy of Sciences of the United States of America 112(31): 9781-9786

25. Oldroyd GE, JA Downie (2008) Coordinating nodule morphogenesis with rhizobial infection in legumes. Annu Rev Plant Biol 59: 519-546

26. Ibáñez F, L Wall, A Fabra (2017) Starting points in plant-bacteria nitrogen-fixing symbioses: intercellular invasion of the roots. J Exp Bot 68(8): 1905-1918

27. Gage DJ (2004) Infection and Invasion of Roots by Symbiotic, Nitrogen-Fixing Rhizobia during Nodulation of Temperate Legumes. Microbiol Mol Biol Rev 68(2): 280-300

28. Murray J (2016) The Cell Cycle in Nodulation, W: Rose R (red) Molecular Cell Biology of the Growth and Differentiation of Plant Cells. CRC Press, str. 220-235

29. Goedhart J, MA Hink, AJ Visser, T Bisseling, TW Gadella, Jr. (2000) In vivo fluorescence correlation microscopy (FCM) reveals accumulation and immobilization of Nod factors in root hair cell walls. Plant J 21(1): 109-119

30. Xiao TT, S Schilderink, S Moling, EE Deinum, E Kondorosi, i in. (2014) Fate map of Medicago truncatula root nodules. Development 141(18): 3517-3528

31. Harrison MJ, S Ivanov (2017) Exocytosis for endosymbiosis: membrane trafficking pathways for development of symbiotic membrane compartments. Curr Opin Plant Biol 38: 101-108

32. Kereszt A, P Mergaert, E Kondorosi (2011) Bacteroid development in legume nodules: evolution of mutual benefit or of sacrificial victims? Mol Plant Microbe Interact 24(11): 1300-1309

33. Montiel J, JA Downie, A Farkas, P Bihari, R Herczeg, i in. (2017) Morphotype of bacteroids in different legumes correlates with the number and type of symbiotic NCR peptides. 114(19): 5041-5046

34. Udvardi M, PS Poole (2013) Transport and metabolism in legume-rhizobia symbioses. Annu Rev Plant Biol 64: 781-805

35. Oldroyd GE (2007) Plant science. Nodules and hormones. Science 315(5808): 52-53

36. Jardinaud MF, S Boivin, N Rodde, O Catrice, A Kisiala, i in. (2016) A Laser Dissection-RNAseq Analysis Highlights the Activation of Cytokinin Pathways by Nod Factors in the Medicago truncatula Root Epidermis. Plant Physiol 171(3): 2256-2276

37. Daviere JM, P Achard (2017) Organ communication: Cytokinins on the move. Nat Plants 3: 17116

38. Zurcher E, B Muller (2016) Cytokinin Synthesis, Signaling, and Function--Advances and New Insights. Int Rev Cell Mol Biol 324: 1-38

39. Sakakibara H (2006) Cytokinins: activity, biosynthesis, and translocation. Annu Rev Plant Biol 57: 431-449

40. Osugi A, H Sakakibara (2015) Q\&A: How do plants respond to cytokinins and what is their importance? BMC Biol 13: 102

41. Zhang X, Y Chen, X Lin, X Hong, Y Zhu, i in. (2013) Adenine phosphoribosyl transferase 1 is a key enzyme catalyzing cytokinin conversion from nucleobases to nucleotides in Arabidopsis. Mol Plant 6(5): 16611672

42. Muller B, J Sheen (2007) Advances in cytokinin signaling. Science 318(5847): 68-69

43. Zurcher E, D Tavor-Deslex, D Lituiev, K Enkerli, PT Tarr, i in. (2013) A robust and sensitive synthetic sensor to monitor the transcriptional output of the cytokinin signaling network in planta. Plant Physiol 161(3): 1066-1075 
44. Romanov GA, SN Lomin, T Schmulling (2018) Cytokinin signaling: from the ER or from the PM? That is the question! New Phytol 218(1): 41-53

45. Lomin SN, YA Myakushina, DV Arkhipov, OG Leonova, VI Popenko, $\mathrm{i}$ in. (2018) Studies of cytokinin receptor-phosphotransmitter interaction provide evidences for the initiation of cytokinin signalling in the endoplasmic reticulum. Funct Plant Biol 45(2): 192-202

46. Niemann MCE, H Weber, T Hluska, G Leonte, SM Anderson, $\mathrm{i}$ in. (2018) The cytokinin oxidase/dehydrogenase CKX1 is a membrane-bound protein requiring homooligomerization in the endoplasmic reticulum for its cellular activity. Plant Physiol 176(3): 2024-2039

47. Zurcher E, J Liu, M di Donato, M Geisler, B Muller (2016) Plant development regulated by cytokinin sinks. Science 353(6303): 1027-1030

48. Gonzalez-Rizzo S, M Crespi, F Frugier (2006) The Medicago truncatula CRE1 cytokinin receptor regulates lateral root development and early symbiotic interaction with Sinorhizobium meliloti. Plant Cell 18(10): 2680-2693

49. Plet J, A Wasson, F Ariel, C Le Signor, D Baker, i in. (2011) MtCRE1-dependent cytokinin signaling integrates bacterial and plant cues to coordinate symbiotic nodule organogenesis in Medicago truncatula. Plant J 65(4): 622-633

50. van Zeijl A, Rik HM Op den Camp, Eva E Deinum, T Charnikhova, H Franssen, i in. (2015) Rhizobium Lipo-chitooligosaccharide Signaling Triggers Accumulation of Cytokinins in Medicago truncatula Roots. Molecular Plant 8(8): 1213-1226

51. Boivin S, T Kazmierczak, M Brault, J Wen, P Gamas, i in. (2016) Different cytokinin histidine kinase receptors regulate nodule initiation as well as later nodule developmental stages in Medicago truncatula. Plant, Cell Environ 39(10): 2198-2209

52. Vernie T, J Kim, L Frances, Y Ding, J Sun, i in. (2015) The NIN Transcription Factor Coordinates Diverse Nodulation Programs in Different Tissues of the Medicago truncatula Root. Plant Cell 27(12): 3410-3424
53. Roudier F, E Fedorova, M Lebris, P Lecomte, J Györgyey, i in. (2003) The Medicago Species A2-Type Cyclin Is Auxin Regulated and Involved in Meristem Formation But Dispensable for Endoreduplication-Associated Developmental Programs. Plant Physiol 131(3): 1091-1103

54. Kohlen W, JLP Ng, EE Deinum, U Mathesius (2018) Auxin transport, metabolism, and signalling during nodule initiation: indeterminate and determinate nodules. J Exp Bot 69(2): 229-244

55. Ng JL, S Hassan, TT Truong, CH Hocart, C Laffont, i in. (2015) Flavonoids and Auxin Transport Inhibitors Rescue Symbiotic Nodulation in the Medicago truncatula Cytokinin Perception Mutant cre1. Plant Cell 27(8): 2210-2226

56. Breakspear A, C Liu, S Roy, N Stacey, C Rogers, i in. (2014) The root hair "infectome" of Medicago truncatula uncovers changes in cell cycle genes and reveals a requirement for Auxin signaling in rhizobial infection. Plant Cell 26(12): 4680-4701

57. Mortier V, M Holsters, S Goormachtig (2012) Never too many? How legumes control nodule numbers. Plant Cell Environ 35(2): 245-258

58. Gamas P, M Brault, MF Jardinaud, F Frugier (2017) Cytokinins in Symbiotic Nodulation: When, Where, What For? Trends Plant Sci 22(9): 792-802

59. Mortier V, E De Wever, M Vuylsteke, M Holsters, S Goormachtig (2012) Nodule numbers are governed by interaction between CLE peptides and cytokinin signaling. Plant J 70(3): 367-376

60.Sasaki T, T Suzaki, T Soyano, M Kojima, H Sakakibara, i in. (2014) Shoot-derived cytokinins systemically regulate root nodulation. Nat Commun 5: 4983

61. Olivares J, EJ Bedmar, J Sanjuan (2013) Biological nitrogen fixation in the context of global change. Mol Plant Microbe Interact 26(5): 486-494

62. Delaux PM, G Radhakrishnan, G Oldroyd (2015) Tracing the evolutionary path to nitrogen-fixing crops. Curr Opin Plant Biol 26: 95-99

\title{
The role of cytokinins in Legume-Rhizobium symbiosis
}

\section{Karolina Jarzyniak ${ }^{\natural}$}

Department of Biochemistry and Biotechnology, Poznan University of Life Sciences, Poznań.

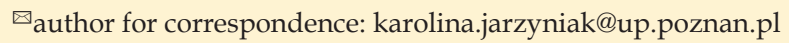

Key words: Biological Nitrogen Fixation, diazotrophy, Rhizobium, Medicago truncatula, nodule morphogenesis, cytokinins

\begin{abstract}
Legume plants have a unique ability to form associations with nitrogen-fixing rhizobial species. An exchange of specific signaling molecules between host and microsymbiont constitutes the first step required both for bacterial infection and the formation of new, root-derived organs, called nodules. Since these two events occur in different root tissues, namely in the rhizodermis and in the underlying cortical cells, their strict regulation and coordination have to exist. An essential role of plant hormones, especially cytokinins, in the modulation of nitrogen-fixing symbiosis has been widely postulated. Activation of the cytokinin signaling pathway in the root cortex, by an unknown signal, is thought to be a key event of the infection process. As a consequence bioactive cytokinins are biosynthesized in the root susceptible zone, and they are a part of a positive feedback loop to trigger cortical cell division and sustain nodule organogenesis. Understanding the genetic mechanisms underlying events that occur in the inner layers of the root is one of the key challenges emerging in the study of symbiotic processes.
\end{abstract}

